\title{
Normalizacja środków smarowych w Polsce
}

\begin{abstract}
$\mathrm{W}$ artykule przedstawiono podstawowe informacje dotyczące normalizacji środków smarowych w Polsce w powiązaniu z normalizacją międzynarodową i europejską. Omówiono podstawę prawną działania polskiej normalizacji - Ustawę z dnia 12 września 2002 r. o normalizacji. Przedstawiono Podkomitet KT 222/PK 3 ds. Olejów Smarowych - organ techniczny krajowej jednostki normalizacyjnej - Polskiego Komitetu Normalizacyjnego PKN, w którego zakresie znajduje się normalizacja środków smarowych. Omówiono zależności miedzy organizacjami normalizacyjnymi: Międzynarodową Organizacją Normalizacyjną ISO, Europejskim Komitetem Normalizacyjnym CEN i Polskim Komitetem Normalizacyjnym PKN. Zaprezentowano normy ujmujące klasyfikację środków smarowych, w szczególności normę ISO 6743-99:2002 Lubricants, industrial oils and related products (class L) - Classification - Part 99: General. Przedstawiono informacje dotyczące prac grupy roboczej CEN/TC 19/WG 33 Bio-lubricants działającej w ramach komitetu technicznego CEN/TC 19 Gaseous and liquid fuels, lubricants and related products of petroleum, synthetic and biological origin.
\end{abstract}

Słowa kluczowe: środki smarowe, normalizacja, klasyfikacja.

\section{Standardization of lubricants in Poland}

The article presents basic data on the standardization of lubricants in Poland in connection with International and European Standardization. The legal basis for the operation of Polish standardization - The Act of 12 September 2002 on standardization was discussed. KT 222/PK 3 Lubricating Oils Sub-Committee - a technical body of the national standardization body - Polish Committee for Standardization PKN, whose scope of work covers the standardization of lubricants is presented. The relationships between standardization organizations: International Organization for Standardization ISO, European Committee for Standardization CEN and Polish Committee for Standardization PKN are discussed. The classification of lubricants according to ISO 6743-99:2002 Lubricants, industrial oils and related products (class L) - Classification - Part 99: General is presented in detail. The work of the CEN/TC 19/WG 33 Bio-lubricants working group within the technical committee CEN/TC/19 Gaseous and liquid fuels, lubricants and related products of petroleum, synthetic and biological origin is presented.

Key words: lubricants, standardization, classification.

\section{Wprowadzenie}

Jednym z celów normalizacji jest ułatwienie wymiany towarów poprzez eliminację barier technicznych w handlu i zapobieganie ich powstawaniu. Normalizacja produktów przerobu ropy naftowej, w tym środków smarowych, jest realizowana: na poziomie międzynarodowym przez Międzynarodową Organizację Normalizacyjną ISO (International Organization for Standardization), na poziomie regionalnym - europejskim przez Europejski Komitet Normalizacyjny CEN (European Committee for Standardization, Comité Européen de Normalisation), w Polsce - przez krajową jednostkę normalizacyjną Polski Komitet Normalizacyjny PKN.
Organem technicznym, w zakresie którego znajduje się tematyka środków smarowych, jest Podkomitet PK 3 ds. Olejów Smarowych Komitetu Technicznego 222 ds. Przetworów Naftowych i Cieczy Eksploatacyjnych. Środki smarowe, pomimo małej ilościowo produkcji, w porównaniu z innymi produktami przerobu ropy naftowej mają niewspółmiernie szeroki asortyment. Znajduje to odzwierciedlenie w zakresie prac normalizacyjnych. Od 2009 r. do września 2017 r. Polski Komitet Normalizacyjny zatwierdził 100 dokumentów normalizacyjnych z zakresu Podkomitetu KT 222/PK 3 ds. Olejów Smarowych. 


\section{Podstawa prawna polskiej normalizacji}

Ustawa z dnia 12 września 2002 r. o normalizacji stanowi: „Polska Norma jest normą krajową, przyjętą w drodze konsensu i zatwierdzoną przez krajową jednostkę normalizacyjną, powszechnie dostępną, oznaczoną - na zasadzie wyłączności - symbolem PN. Polska Norma może być wprowadzeniem normy europejskiej lub międzynarodowej. Wprowadzenie to może nastąpić w języku oryginału" [17]. Polska Norma może być wydana w języku oryginału, ponieważ jednym z warunków przyjęcia Polski do Unii Europejskiej było włączenie polskiej krajowej jednostki normalizacyjnej - Polskiego Komitetu Normalizacyjnego PKN do
Europejskiego Komitetu Normalizacyjnego CEN, a to wymagało wprowadzenia Norm Europejskich (EN) do zbioru Polskich Norm (PN-EN). Ustawa o normalizacji stanowi: „Stosowanie Polskich Norm jest dobrowolne” [17]. Obecnie mamy więc do czynienia $z$ „normami aktualnymi”, a nie „normami obowiązującymi”. Zgodnie z ustawą: „Polskie Normy korzystają z ochrony jak utwory literackie, a autorskie prawa majątkowe do nich przysługują krajowej jednostce normalizacyjnej" [17]. Polskie Normy nie stanowią informacji publicznej [4]. Z treścią norm można zapoznać się w Punktach Informacji Normalizacyjnej.

\section{Członkostwo PKN w Europejskim Komitecie Normalizacyjnym CEN i Międzynarodowej Organizacji Normalizacyjnej ISO}

PKN od 2004 r. jest członkiem CEN. Członkami CEN są krajowe jednostki normalizacyjne 34 państw: 28 państw Unii Europejskiej oraz byłej Jugosłowiańskiej Republiki Macedonii, Serbii, Turcji, Islandii, Norwegii i Szwajcarii. Członkostwo w CEN skutkuje obowiązkiem wprowadzenia do zbioru norm krajowych wszystkich norm europejskich i wycofaniem norm sprzecznych. Jako kraj członkowski mamy obowiązek wprowadzenia norm europejskich (EN) do zbioru norm polskich, jako PN-EN, w oryginalnej wersji językowej z przetłumaczonym na język polski tytułem i abstraktem [16]. PKN od 1947 r. jest członkiem Międzynarodowej Organizacji Normalizacyjnej ISO. Członkami ISO są krajowe jednostki normalizacyjne 162 państw [7]. Członkostwo w ISO nie skutkuje obowiązkiem wprowadzania norm ISO [4]. Część norm ISO, których tematyka nie jest ujęta w normach EN, jest implementowana przez CEN i zatwierdzana jako EN ISO. Normy te są następnie, już obligatoryjnie, wprowadzane do zbioru norm państw członkowskich jako normy uznaniowe - przez PKN jako PN-EN ISO [4].

\section{Umiejscowienie normalizacji środków smarowych w PKN}

W PKN tematyka środków smarowych, obejmująca oleje smarowe i specjalne środki smarowe pochodzenia naftowego, produkty podobne pochodzenia syntetycznego i biologicznego, umiejscowiona jest w Podkomitecie KT 222/ PK 3 ds. Olejów Smarowych Komitetu Technicznego 222 ds. Przetworów Naftowych i Cieczy Eksploatacyjnych.
Sekretariaty Podkomitetu KT 222/PK 3 i Komitetu KT 222 prowadzi Instytut Nafty i Gazu - Państwowy Instytut Badawczy. W skład Podkomitetu wchodzi 14 członków - podmiotów, z których każdy może delegować trzech reprezentantów. W tablicy 1 wymieniono podmioty, które są członkami Podkomitetu KT 222/PK 3 ds. Olejów Smarowych [4].

Tablica 1. Członkowie KT 222/PK 3 ds. Olejów Smarowych [4]

\begin{tabular}{|l|l|}
\hline Grupa LOTOS S.A. & ORLEN OIL Sp. z o.o. \\
\hline Instytut Badań i Rozwoju Motoryzacji BOSMAL Sp. z o.o. & ORLEN Laboratorium S.A. \\
\hline Instytut Nafty i Gazu - Państwowy Instytut Badawczy & Polska Organizacja Przemysłu i Handlu Naftowego \\
\hline Instytut Techniczny Wojsk Lotniczych & Polskie Centrum Badań i Certyfikacji S.A. \\
\hline Instytut Transportu Samochodowego & Przemysłowy Instytut Motoryzacji \\
\hline LOTOS Lab Sp. z o.o. & Polwax S.A. \\
\hline LOTOS Oil Sp. z o.o. & Boccard Polska Sp. z o.o. \\
\hline
\end{tabular}

\section{Prace Podkomitetu KT222/PK3}

W latach 2009-2017 Polski Komitet Normalizacyjny zatwierdził i opublikował 100 dokumentów normalizacyj- nych - norm klasyfikacyjnych, norm produktowych, metod badań, raportów, specyfikacji technicznych - opracowanych 
przez Podkomitet ds. Olejów Smarowych KT 222/PK 3 [4]. W tablicy 2 zestawiono rodzaje podstawowych dokumentów normalizacyjnych opracowywanych przez organizacje normalizacyjne: Europejski Komitet Normalizacyjny CEN, Międzynarodową Organizację Normalizacyjną ISO, Polski Komitet Normalizacyjny PKN oraz krajową jednostkę normalizacyjną Niemiec Deutsches Institut für Normung. Niebieskim kolorem wyróżniono te dokumenty normalizacyjne - normy europejskie, których wersje krajowe w języku oryginału ukazują się w krajach członkowskich CEN w terminie do 6 miesięcy od opublikowania przez CEN - co obligatoryjnie wynika z członkostwa w CEN.

W tablicy 3 podano liczbę dokumentów normalizacyjnych opracowanych przez KT 222/PK 3, opublikowanych przez PKN w latach 2009-2017. Niebieskim kolorem, analogicznie do tablicy 2, wyróżniono te dokumenty normalizacyjne - normy europejskie, których wersje krajowe w języku oryginału ukazują się obligatoryjnie w krajach członkowskich CEN w terminie do 6 miesięcy od opublikowania przez CEN. Zielonym kolorem wyróżniono te dokumenty normalizacyjne - polskie wersje norm europejskich, norm międzynarodowych, specyfikacji technicznych, raportów technicznych i normy własne, które zostały opracowane z inicjatywy Podkomitetu KT 222/PK 3. Spośród 100 dokumentów normalizacyjnych 12 w języku angielskim ukazało się dlatego, że PKN jest członkiem CEN. Pozostałych 88 dokumentów - w języku polskim - zostało opracowanych przez KT 222/PK 3 z inicjatywy i dzięki zaangażowaniu członków Podkomitetu.

Tablica 2. Dokumenty normalizacyjne opracowywane przez CEN, ISO, PKN oraz DIN

\begin{tabular}{|c|c|c|}
\hline $\begin{array}{c}\text { Organizacja } \\
\text { normalizacyjna }\end{array}$ & $\begin{array}{l}\text { Symbol dokumentu } \\
\text { normalizacyjnego* }\end{array}$ & Dokument normalizacyjny ${ }^{*}$ \\
\hline $\mathrm{CEN}$ & $\begin{array}{l}\text { EN } \\
\text { EN ISO } \\
\text { CEN/TR } \\
\text { CEN/TS }\end{array}$ & $\begin{array}{l}\text { Norma Europejska } \\
\text { Norma Europejska wprowadzająca Normę Międzynarodową } \\
\text { Raport Techniczny CEN } \\
\text { Specyfikacja Techniczna CEN }\end{array}$ \\
\hline ISO & $\begin{array}{c}\text { ISO } \\
\text { ISO/TS }\end{array}$ & $\begin{array}{l}\text { Norma Międzynarodowa } \\
\text { Specyfikacja Techniczna ISO }\end{array}$ \\
\hline PKN & $\begin{array}{l}\text { PN-EN } \\
\text { PN-EN ISO } \\
\text { PN-ISO } \\
\text { PN-C }\end{array}$ & $\begin{array}{l}\text { Norma Polska wprowadzająca Normę Europejską } \\
\text { Norma Polska wprowadzająca EN ISO } \\
\text { Norma Polska wprowadzająca Normę Międzynarodową } \\
\text { Norma Polska własna }\end{array}$ \\
\hline DIN & DIN & Norma własna DIN Deutsches Institut für Normung \\
\hline
\end{tabular}

* Niebieskim kolorem wyróżniono te dokumenty normalizacyjne - normy europejskie, których wersje krajowe w języku oryginału ukazują się w krajach członkowskich CEN w terminie do 6 miesięcy od opublikowania przez CEN.

Tablica 3. Dokumenty normalizacyjne KT 222/PK 3 opublikowane przez PKN w latach 2009-2017

\begin{tabular}{|c|c|c|c|c|}
\hline \multicolumn{2}{|c|}{$\begin{array}{c}\text { Organizacje } \\
\text { normalizacyjne - } \\
\text { dokumenty }\end{array}$} & \multirow{2}{*}{$\begin{array}{c}\text { Normy opublikowane } \\
\text { przez PKN po } \\
\text { ukazaniu się EN* }\end{array}$} & \multirow{2}{*}{ 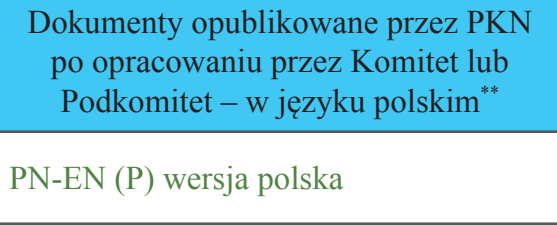 } & \multirow{2}{*}{$\begin{array}{c}\begin{array}{c}\text { Liczba dokumentów } \\
\text { opracowanych przez } \\
\text { KT } 222 / \text { PK } 3\end{array} \\
2(\mathrm{E}) / 3(\mathrm{P})\end{array}$} \\
\hline \multirow{4}{*}{ CEN } & EN & & & \\
\hline & EN ISO & $\begin{array}{l}\text { PN-EN ISO (E) } \\
\text { wersja angielska }\end{array}$ & PN-EN ISO (P) wersja polska & $10(\mathrm{E}) / 16(\mathrm{P})$ \\
\hline & CEN/TR & - & PKN-CEN/TR & 2 \\
\hline & $\mathrm{CEN} / \mathrm{TS}$ & - & PKN-CEN/TS & 1 \\
\hline \multirow{2}{*}{ ISO } & ISO & - & PN-ISO & 56 \\
\hline & ISO/TS & - & PKN-ISO/TS & 2 \\
\hline PKN & $\mathrm{PN}$ & - & $\begin{array}{l}\text { PN-C Polska Norma własna opracowana } \\
\text { na podstawie normy PN wycofanej }\end{array}$ & 2 \\
\hline DIN & DIN & - & $\begin{array}{l}\text { PN-C Polska Norma własna identyczna } \\
\text { z normą krajową DIN }\end{array}$ & 6 \\
\hline
\end{tabular}

"Niebieskim kolorem wyróżniono te dokumenty normalizacyjne - normy europejskie, których wersje krajowe w języku oryginału ukazują się w krajach członkowskich CEN w terminie do 6 miesięcy od opublikowania przez CEN.

** Zielonym kolorem wyróżniono te dokumenty normalizacyjne - polskie wersje norm europejskich, norm międzynarodowych, specyfikacji technicznych, raportów technicznych i normy własne, które zostały opracowane z inicjatywy Podkomitetu KT222/PK3. 
Wprowadzenie przez PKN norm europejskich EN i EN-ISO jako PN-EN i PN-EN ISO w języku oryginału do zbioru polskich norm wynika z członkostwa w CEN. Natomiast opracowanie polskich wersji językowych norm europejskich PN-EN, wprowadzenie do zbioru PN i opracowanie polskich wersji norm międzynarodowych PN-ISO, specyfikacji technicznych PKN-CEN/TS i PKN-ISO/TS, raportów technicznych PKN-CEN/TR oraz opracowanie norm własnych PN-C, czy to wprowadzających normy innych organizacji krajowych, czy przygotowanych we własnym zakresie (z wyznaczeniem precyzji dla metody badań), jest zależne od organu technicznego zajmującego się tematyką dokumentu. Jeżeli dany temat znajdzie się w programie organu technicznego można rozpocząć odpowiednią procedurę. Opracowanie wyżej wymienionych dokumentów normalizacyjnych z zakresu Podkomitetu ds. Olejów Smarowych było możliwe dzięki finansowemu zaangażowaniu członków Podkomitetu: Grupy LOTOS S.A. i ORLEN OIL Sp. o.o.

Wśród norm opracowanych przez KT 222/PK 3 znajdują się tzw. normy własne, które nie są wdrożeniem istniejącego dokumentu innej organizacji normalizacyjnej. Opracowanie normy własnej na metodę badania wymaga przeprowadzenia badań międzylaboratoryjnych w celu wyznaczenia precyzji metody.

Tablica 4. Normy własne opracowywane przez KT 222/PK 3

\begin{tabular}{|l|l|c|}
\hline \multicolumn{1}{|c|}{ Norma wycofana bez zastąpienia } & \multicolumn{1}{|c|}{ Norma opracowana/w trakcie opracowania } & Program \\
\hline $\begin{array}{l}\text { PN-C-04089:1958 Przetwory naftowe - } \\
\text { Oznaczanie zawartości stałych ciał obcych } \\
\text { (wycofana 15.02.2006 r.) }\end{array}$ & $\begin{array}{l}\text { PN-C-04361:2017-02 Przetwory naftowe - Oznaczanie } \\
\text { zawartości ciał stałych obcych - Metoda ekstrakcyjna } \\
\text { (zatwierdzona 15.02.2017 r.) }\end{array}$ & 2015 \\
\hline $\begin{array}{l}\text { PN-C-04147:1976 Przetwory naftowe - } \\
\text { Badanie własności smarnych olejów i smarów } \\
\text { (wycofana 26.10.2012 r.) }\end{array}$ & $\begin{array}{l}\text { PN-C-04362:2017-03 Przetwory naftowe - Badanie } \\
\text { kłaściwości smarnych olejów i smarów } \\
\text { (zatwierdzona 23.03.2017 r.) }\end{array}$ & 2015 \\
\hline $\begin{array}{l}\text { PN-C-04161:1982 Przetwory naftowe - } \\
\text { Pomiar penetracji parafin i cerezyn } \\
\text { (wycofana 4.06.2014 r.) }\end{array}$ & $\begin{array}{l}\text { prPN-C-04313:... Przetwory naftowe - Oznaczanie } \\
\text { penetracji parafin i cerezyn } \\
\text { (termin zatwierdzenia: 22.05.2018 r.) }\end{array}$ & 2016 \\
\hline $\begin{array}{l}\text { PN-C-04064:1984 Przetwory naftowe - } \\
\text { Oznaczanie odczynu wyciągu wodnego } \\
\text { (wycofana 27.07.2015 r.) }\end{array}$ & $\begin{array}{l}\text { prPN-C-96060 Przetwory naftowe - Oznaczanie odczy- } \\
\text { nu wyciągu wodnego } \\
\text { (termin zatwierdzenia: ...) }\end{array}$ & 2017 \\
\hline
\end{tabular}

\section{Ogólna klasyfikacja przetworów naftowych i produktów podobnych}

Szczególną pozycję pośród norm opracowanych przez KT 222/PK 3 stanowi grupa norm klasyfikacyjnych. Przeróbka ropy naftowej umożliwia uzyskiwanie różnych produktów, półproduktów i surowców. Podział przetworów naftowych i produktów podobnych został przedstawiony w normie ISO 8681:1986 Petroleum products and lubricants - Method of classification - Definition of classes [11], opracowanej w wersji polskiej przez KT 222/PK 3 jako PN-ISO 8681:2017-02 Przetwory naftowe i środki smarowe - Metoda klasyfikacji - Definicja klas, w której ustanowiono ogólny system klasyfikacji dotyczący przetworów naftowych, środków smarowych i produktów podobnych oraz zdefiniowano klasy przetworów naftowych, środków smarowych i produktów podobnych, a także podano oznaczenie tych klas. Zasady klasyfikacji odnoszące się do każdej klasy produktu są określone w odpowiednich normach międzynarodowych [15]. W tablicy 5 przedstawiono podział przetworów naftowych i produktów podobnych na klasy według normy PN-ISO ISO 8681.
Tablica 5. Ogólna klasyfikacja przetworów naftowych i produktów podobnych według PN-ISO ISO 8681 [15]

\begin{tabular}{|c|l|}
\hline Klasa & Oznaczenie \\
\hline F & Paliwa \\
\hline S & Rozpuszczalniki i surowce dla przemysłu chemicznego \\
\hline L & Środki smarowe, oleje przemysłowe i produkty podobne \\
\hline W & Woski \\
\hline B & Asfalty \\
\hline
\end{tabular}

Środki smarowe obejmują oleje smarowe, smary plastyczne i specyfiki naftowe. Pomimo małej ilościowo produkcji, w porównaniu z innymi produktami naftowymi, środki smarowe mają największą gamę asortymentu. Charakteryzują się one różnym składem chemicznym i różnymi parametrami użytkowymi, co jest spowodowane bardzo różnorodnym ich zastosowaniem [6]. Klasyfikację lepkościową olejów silnikowych opracowało i stale aktualizuje amerykańskie Stowarzyszenie Inżynierów Samochodowych SAE 
(Society of Automotive Engineers). Jakość olejów silnikowych określana jest w oparciu o amerykańską klasyfikację API (American Petroleum Institute) oraz o klasyfikację europejską ACEA (Association des Constructeurs Européens d'Automobiles) [5].

W ISO klasyfikację lepkościową dla przemysłowych środków smarowych ujmuje norma ISO 3448:1992 Industrial liquid lubricants - ISO viscosity classification [9] opracowana w wersji polskiej przez Podkomitet KT 222/PK 3 ds. Olejów Smarowych jako PN-ISO 3448:2009 Przemystowe ciekte środki smarowe - Klasyfikacja lepkościowa ISO [13]. Klasyfikację środków smarowych, odwołującą się do możliwie wielu obszarów, w których środki smarowe, oleje przemysłowe i produkty podobne są wykorzystywane, ujmuje norma ISO 6743-99 Lubricants, industrial oils and related products (class L) - Classification - Part 99: General [10] opracowana w wersji polskiej przez Podkomitet KT 222/PK 3 jako PN-ISO 6743-99:2009 Środki smarowe, oleje przemystowe i produkty podobne (klasa L) - Klasyfikacja - Część 99: Postanowienia ogólne [14].

\section{Klasyfikacja środków smarowych według normy ISO 6743}

PN-ISO 6743-99:2009 Środki smarowe, oleje przemystowe i produkty podobne (klasa L) - Klasyfikacja - Część 99: Postanowienia ogólne dzieli środki smarowe, oleje przemysłowe i produkty podobne (klasę L) na 18 grup (Family). Szczegółowa klasyfikacja 15 grup podana jest w odpowiednich częściach normy ISO 6743-99.

Wszystkie 15 części normy klasyfikacyjnej ISO 6743, ujmujące 15 grup produktów, jak również normy na wymagania dla odpowiednich produktów, zostały opracowane przez
Podkomitet KT 222/PK 3 jako normy polskie wprowadzające normy międzynarodowe ISO lub normy europejskie EN-ISO w języku polskim. W tablicy 5 zestawiono: w pierwszej kolumnie - 15 części normy klasyfikacyjnej PN-ISO 6743, w drugiej kolumnie - odpowiadające im normy (PN-ISO) i specyfikacje techniczne (PKN-ISO/TS) na wymagania dla środków smarowych, olejów przemysłowych i produktów podobnych należących do klasy L, zgodnie z ogólną klasyfikacją przetworów naftowych i produktów podobnych według PN-ISO ISO 8681.

Tablica 6. Części normy ISO 6743-99 Lubricants, industrial oils and related products (class L) - Classification - Part 99: General i odpowiednio normy PN-ISO 6743-99:2009 Środki smarowe, oleje przemysłowe i produkty podobne (klasa L) Klasyfikacja-Część 99: Postanowienia ogólne [10, 14]

\begin{tabular}{|c|c|}
\hline $\begin{array}{c}\text { Części normy ISO } 6743 \\
\text { ujmujące poszczególne grupy produktów - Family }\end{array}$ & $\begin{array}{l}\text { Części normy PN-ISO } 6743 \\
\text { ujmujące poszczególne grupy produktów }\end{array}$ \\
\hline Part 1: Family A - Total loss systems & Część 1: Grupa A - Układy smarowania przelotowego \\
\hline $\begin{array}{l}\text { Part 2: Family F - Spindle bearings, bearings and associated } \\
\text { clutches }\end{array}$ & Część 2: Grupa F - Wrzeciona, łożyska i sprzęgła współpracujące \\
\hline Part 3: Family D - Compressors & Część 3: Grupa D - Sprężarki \\
\hline Part 4: Family H - Hydraulic systems & Część 4: Grupa H - Układy hydrauliczne \\
\hline Part 5: Family $\mathrm{T}-$ Turbines & Część 5: Grupa T - Turbiny \\
\hline Part 6: Family C - Gears & Część 6: Grupa C-Przekładnie \\
\hline Part 7: Family M-Metalworking & Część 7: Grupa M - Obróbka metali \\
\hline Part 8: Family $\mathrm{R}$ - Temporary protection against corrosion & Część 8: Grupa R - Środki ochrony czasowej przed korozją \\
\hline Part 9: Family X - Greases & Część 9: Grupa X - Smary plastyczne \\
\hline Part 10: Family Y - Miscellaneous & Część 10: Grupa Y - Inne zastosowania \\
\hline Part 11: Family P - Pneumatic tools & Część 11: Grupa P - Narzędzia pneumatyczne \\
\hline Part 12: Family Q - Heat transfer fluids & Część 12: Grupa Q - Ciekłe nośniki ciepła \\
\hline Part 13: Family G - Slideways & Część 13: Grupa G - Prowadnice ślizgowe \\
\hline Part 14: Family U - Heat treatment & Część 14: Grupa U - Obróbka cieplna \\
\hline Part 15: Family E - Internal combustion engine oils & Część 15: Grupa E - Oleje do silników spalinowych \\
\hline
\end{tabular}


Tablica 7. PN-ISO 6743 - normy klasyfikacyjne i normy na wymagania

\begin{tabular}{|c|c|}
\hline $\begin{array}{l}\text { Części normy klasyfikacyjnej } \\
\text { PN-ISO } 6743\end{array}$ & $\begin{array}{l}\text { Polskie normy PN-ISO i specyfikacje techniczne (PKN-ISO/TS) na wymagania dla } \\
\text { środków smarowych, olejów przemysłowych i produktów podobnych (klasa L) }\end{array}$ \\
\hline $\begin{array}{l}\text { PN-ISO 6743-1:2009 } \\
\text { Grupa A - Układy smarowania przelotowego }\end{array}$ & PN-ISO 19378:2012 Środki smarowe do obrabiarek - Kategorie i wymagania \\
\hline $\begin{array}{l}\text { PN-ISO 6743-2:2009 } \\
\text { Grupa F - Wrzeciona, łożyska i sprzęgła } \\
\text { współpracujące }\end{array}$ & PN-ISO 19378:2012 Środki smarowe do obrabiarek - Kategorie i wymagania \\
\hline $\begin{array}{l}\text { PN-ISO 6743-3:2009 } \\
\text { Grupa D - Sprężarki }\end{array}$ & - \\
\hline $\begin{array}{l}\text { PN-EN ISO 6743-4:2015-09 } \\
\text { Grupa H - Układy hydrauliczne }\end{array}$ & $\begin{array}{l}\text { PN-ISO 11158:2012 Grupa H (układy hydrauliczne) - Wymagania dla olejów kate- } \\
\text { gorii HH, HL, HM, HV i HG } \\
\text { PN-ISO 15380:2012 Grupa H (Układy hydrauliczne) - Wymagania dla kategorii } \\
\text { HETG, HEPG, HEES i HEPR } \\
\text { PN-EN ISO 12922:2013-05 Grupa H (Układy hydrauliczne) - Wymagania dla cieczy } \\
\text { hydraulicznych kategorii HFAE, HFAS, HFB, HFC, HFDR i HFDU } \\
\text { PN-ISO 19378:2012 Środki smarowe do obrabiarek - Kategorie i wymagania } \\
\text { PN-ISO 7745:2014-08 Hydrauliczne systemy przenoszenia energii - Ciecze trudno- } \\
\text { palne (FR) - Wymagania i wytyczne stosowania }\end{array}$ \\
\hline $\begin{array}{l}\text { PN-ISO 6743-5:2009 } \\
\text { Grupa T - Turbiny }\end{array}$ & $\begin{array}{l}\text { PN-ISO 8068:2009 Grupa T (Turbiny) - Wymagania dla olejów smarowych do turbin } \\
\text { PN-ISO 10050:2014-10 Grupa T (Turbiny) - Wymagania dla cieczy do turbin na ba- } \\
\text { zie estrów trójarylofosforanowych (kategoria ISO-L-TCD) } \\
\text { PKN-ISO/TS 11366:2013-10 Przetwory naftowe i produkty podobne - Wytyczne } \\
\text { eksploatacji olejów smarowych do turbin parowych, gazowych i skojarzonych ukła- } \\
\text { dów gazowo-parowych }\end{array}$ \\
\hline $\begin{array}{l}\text { PN-ISO 6743-6:2013-03 } \\
\text { Grupa C - Przekładnie }\end{array}$ & $\begin{array}{l}\text { PN-ISO 12925-1:2009 Grupa C (Przekładnie) - Część 1: Wymagania dla środków } \\
\text { smarowych do zamkniętych przekładni zębatych } \\
\text { PN-ISO 19378:2012 Środki smarowe do obrabiarek - Kategorie i wymagania }\end{array}$ \\
\hline $\begin{array}{l}\text { PN-ISO 6743-7:2009 } \\
\text { Grupa M - Obróbka metali }\end{array}$ & $\begin{array}{l}\text { PKN-ISO/TS 12927:2011 Grupa M (Obróbka metali) - Wytyczne do opracowywa- } \\
\text { nia wymagań }\end{array}$ \\
\hline $\begin{array}{l}\text { PN-ISO 6743-8:2009 } \\
\text { Grupa R - Czasowa ochrona przed korozją }\end{array}$ & $\begin{array}{l}\text { PKN-ISO/TS 12928:2011 Grupa R (Środki ochrony czasowej przed korozją) - } \\
\text { Wytyczne do opracowywania wymagań }\end{array}$ \\
\hline $\begin{array}{l}\text { PN-ISO 6743-9:2009 } \\
\text { Grupa X - Smary plastyczne }\end{array}$ & $\begin{array}{l}\text { PN-ISO 12924:2012 Grupa X (Smary) - Wymagania } \\
\text { PN-ISO 19378:2012 Środki smarowe do obrabiarek - Kategorie i wymagania }\end{array}$ \\
\hline $\begin{array}{l}\text { PN-ISO 6743-10:2014-10 } \\
\text { Grupa Y - Inne zastosowania }\end{array}$ & - \\
\hline $\begin{array}{l}\text { PN-ISO 6743-11:2014-10 } \\
\text { Grupa P - Narzędzia pneumatyczne }\end{array}$ & - \\
\hline $\begin{array}{l}\text { PN-ISO 6743-12:2012 } \\
\text { Grupa Q - Ciekłe nośniki ciepła }\end{array}$ & - \\
\hline $\begin{array}{l}\text { PN-ISO 6743-13:2013-03 } \\
\text { Grupa G - Prowadnice ślizgowe }\end{array}$ & PN-ISO 19378:2012 Środki smarowe do obrabiarek - Kategorie i wymagania \\
\hline $\begin{array}{l}\text { PN-ISO 6743-14:2012 } \\
\text { Grupa U - Obróbka cieplna }\end{array}$ & - \\
\hline $\begin{array}{l}\text { PN-ISO 6743-15:2015-06 } \\
\text { Grupa E - Oleje do silników wewnętrznego } \\
\text { spalania }\end{array}$ & $\begin{array}{l}\text { PN-ISO 13738:2015-05 Grupa E (Oleje do silników spalinowych) - Wymagania dla } \\
\text { olejów do dwusuwowych silników benzynowych (kategorie EGB, EGC i EGD) } \\
\text { PN-ISO 24254:2014-11 Grupa E (oleje do silników spalinowych) - Wymagania dla } \\
\text { olejów do zastosowań w benzynowych silnikach czterosuwowych motocykli i zinte- } \\
\text { growanych układów przeniesienia napędu (kategorie EMA i EMB) }\end{array}$ \\
\hline
\end{tabular}




\section{Środki smarowe, oleje przemysłowe i produkty podobne w ISO}

W ISO tematyką środków smarowych zajmuje się Komitet Techniczny (TC) ISO/TC 28 Petroleum products and related products of synthetic or biological origin, w którym PKN ma członkostwo czynne (P-Member). PKN jest również członkiem Podkomietów (SC):

- TC 28/SC 2 Measurement of petroleum and related products (członkostwo bierne O-Member),

- TC 28/SC 4 Classifications and specifications (członkostwo czynne P-Member) [3].
Współpraca Podkomitetu KT 222/PK 3 z wyżej wymienionymi Podkomitetami ISO polega na opiniowaniu dokumentów, uczestnictwie w głosowaniach oraz dostarczaniu dokumentów informacyjnych. Przekazując uwagi, mamy możliwość wpływania na treść dokumentów normalizacyjnych. W przypadku członkostwa czynnego opiniowanie i głosowanie jest obowiązkowe, natomiast w przypadku członkostwa biernego wszystkie dokumenty mają charakter informacyjny.

\section{Środki smarowe, oleje przemysłowe i produkty podobne w CEN}

W CEN tematyką środków smarowych zajmuje się CEN/ TC 19/WG 33 Bio-lubricants - jedna z siedemnastu Grup Roboczych (WG) działających w ramach Komitetu Technicznego CEN/TC 19 Gaseous and liquid fuels, lubricants and related products of petroleum, synthetic and biological origin [1]. W zakresie zadań KT 222/PK 3 znajduje się współpraca z CEN/TC 19/WG 33, która polega na opiniowaniu dokumentów normalizacyjnych i uczestnictwie w głosowaniach, podobnie jak w przypadku członkostwa czynnego w ISO.

Aktualnie w Podkomitecie KT 222/PK 3 trwają prace nad polską wersją opracowanej w CEN/TC 19/WG 33 normy EN 16807:2016 Liquid petroleum products - Biolubricants - Criteria and requirements of bio-lubricants and bio-based lubricants [8], która została opublikowana przez CEN w październiku 2016 r. Polska norma uznaniowa PN-EN 16807:2016-11 Ciekłe przetwory naftowe - Biośrodki smarowe - Kryteria i wymagania dla biośrodków smarowych i dla biobazowych środków smarowych $\mathrm{w}$ wersji angielskiej ukazała się w listopadzie 2016 r. Polska wersja normy w wersji ang. ukazała się w ukaże się w 2018 r. jako równoważna z wersją uznaniową PN-EN 16807:2016-11 Ciekte przetwory naftowe - Biośrodki smarowe - Kryteria i wymagania dla biośrodków smarowych i dla biobazowych środków smarowych, pod tym samym numerem. W normie określono termin biośrodek smarowy oraz minimalne wymagania dla wszystkich rodzajów biośrodków smarowych i biobazowych środków smarowych, podczas gdy EEL (European Ecolabel for Lubricants) odnosi się do konkretnych rodzin biośrodków smarowych. Opisano również krótko istotne metody badań wymagane w odniesieniu do charakterystyki biośrodków smarowych. Przedstawiono zalecenia dla powiązanych norm w obszarze biodegra- dowalności, funkcjonalności produktu oraz ilości różnych surowców odnawialnych i/lub różnej zawartości biobaz wykorzystywanych podczas wytwarzania tych biośrodków smarowych tworzących jedną grupę produktów [12].

W tablicy 8 podano tematy prac na wczesnym etapie opracowania, którymi zajmuje się aktualnie grupa robocza CEN/TC 19/WG 33.

Tablica 8 . Tematy normalizacyjne w programie CEN/TC 19/WG 33 [2]

Work item: Liquid petroleum products - Determination of aerobic biological degradation of fully formulated lubricants in an aqueous solution - Test method based on $\mathrm{CO}_{2}$-production (initial date 2015)

Work item: Liquid petroleum products - Determination of aerobic biological degradation of fully formulated lubricants in an aqueous solution - Test method based on $\mathrm{O}_{2}$-consumption (initial date 2015)

W 2014 r. ukazała się Polska Norma PN-EN 16575:2014-12 Produkty biobazowe - Terminologia - w wersji angielskiej, wprowadzająca Normę Europejską EN 16575:2014 Bio-based products - Vocabulary, opracowaną przez Komitet Techniczny CEN/TC 411 Bio-based products [1]. W normie tej określono ogólne terminy, które mają być stosowane w dziedzinie produktów biobazowych, w tym horyzontalne aspekty istotne dla norm dotyczących produktów biobazowych [4]. Odpowiednikiem Komitetu CEN/TC 411 jest Komitet Techniczny PKN/KT 319 ds. Produktów Biobazowych. Zakres tematyczny PKN/KT 319 obejmuje następujące zagadnienia związane z produktami biobazowymi: terminologia, wymagania, metody badań, pobieranie i przygotowywanie próbek oraz kryteria zrównoważonego rozwoju [4].

\section{Podsumowanie}

Normalizacja środków smarowych - grupy wyrobów o szczególnie dużej różnorodności zastosowania - reali- zowana jest przez organizacje normalizacyjne na poziomie międzynarodowym, europejskim i krajowym. Przynależność 
krajowej jednostki normalizacyjnej - Polskiego Komitetu Normalizacyjnego do organizacji normalizacyjnych, międzynarodowej ISO i europejskiej CEN, wyznacza odpowiednie zadania do wykonania przez powołany do tych prac organ techniczny PKN, którym jest Podkomitet KT 222/ PK 3 ds. Olejów Smarowych. Sekretariat Podkomitetu KT 222/PK 3 prowadzi Instytut Nafty i Gazu - Państwowy Instytut Badawczy.
W bieżącym roku Polski Komitet Normalizacyjny przyznał Instytutowi nagrodę Kompas Normalizacji. Wyróżnienie to przyznawane jest za szczególny wkład w promocję normalizacji. Tak wysoka ocena działalności normalizacyjnej Instytutu przez Polski Komitet Normalizacyjny to rezultat wieloletniej bardzo dobrej współpracy Instytutu i środowisk zaangażowanych w prace normalizacyjne z obszaru ropy i gazu, w tym również z obszaru środków smarowych.

Prosimy cytować jako: Nafta-Gaz 2017, nr 12, s. 980-987, DOI: 10.18668/NG.2017.12.10

Artykuł nadesłano do Redakcji 21.07.2017 r. Zatwierdzono do druku 21.09.2017 r.

Artykuł powstał na podstawie pracy INiG - PIB pt.: Podstawy merytoryczne dostosowania norm polskich z zakresu ropy i gazu do wymagań UE - nr zlecenia: 12/TN/DN/2017/01, nr archiwalny: DK-5100-63/17.

\section{Literatura}

[1] European Committee for Standardization; https://www.cen. eu (dostęp: lipiec 2017).

[2] Informacje własne z prac CEN/TC19 (dostęp: lipiec 2017).

[3] International Organization for Standardization; http://www. iso.org (dostęp: lipiec 2017).

[4] Polski Komitet Normalizacyjny; http://www.pkn.pl (dostęp: lipiec 2017).

[5] Ptak S.: Klasyfikacja jakościowa i charakterystyka przemystowych środków smarowych. Nafta-Gaz 2012, nr 7, s. 454-461.

[6] Ptak S., Jakóbiec J.: Ropa naftowa jako główny surowiec energetyczno-przemystowy. Nafta-Gaz 2016, nr 6, s. 451-460, DOI: $10.18668 /$ NG.2016.06.09.

\section{Akty prawne i normatywne}

[7] Dyrektywy ISO/IEC. Część 1. Procedury prac technicznych, wersja polska, Polski Komitet Normalizacyjny, grudzień, 2014, www.pkn.pl (dostęp: lipiec 2017).

[8] EN 16807:2016 Liquid petroleum products - Bio-lubricants - Criteria and requirements of bio-lubricants and bio-based lubricants.

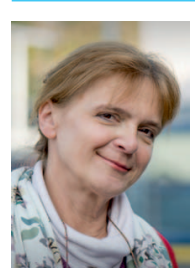

Mgr inż. Zofia BŁASZKIEWICZ

Starszy specjalista badawczo-techniczny;

kierownik Zakładu Normalizacji.

Instytut Nafty i Gazu - Państwowy Instytut Badawczy

ul. Lubicz 25 A

31-503 Kraków

E-mail: zofia.blaszkiewicz@inig.pl
[9] ISO 3448:1992 Industrial liquid lubricants - ISO viscosity classification.

[10] ISO 6743-99:2002 Lubricants, industrial oils and related products (class L) - Classification - Part 99: General.

[11] ISO 8681:1986 Petroleum products and lubricants - Method of classification - Definition of classes.

[12] PN-EN 16807:2016-11 wersja angielska, Ciekte przetwory naftowe - Biośrodki smarowe - Kryteria i wymagania dla biośrodków smarowych i dla biobazowych środków smarowych.

[13] PN-ISO 3448:2009 wersja polska, Przemystowe ciekte środki smarowe - Klasyfikacja lepkościowa.

[14] PN-ISO 6743-99:2009 wersja polska, Środki smarowe, oleje przemystowe i produkty podobne (klasa L) - Klasyfikacja-Część 99: Postanowienia ogólne.

[15] PN-ISO 8681:2017-02 wersja polska, Przetwory naftowe i środki smarowe - Metoda klasyfikacji - Definicja klas.

[16] Przepisy Wewnętrzne CEN/CENELEC, Część 2, 2013; www. pkn.pl (dostęp: lipiec 2017).

[17] Ustawa z dnia 12 września 2002 r. o normalizacji (Dz.U. z 2002 r. nr 169, poz. 1386).

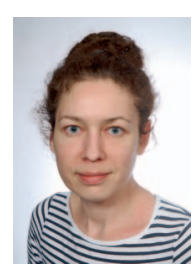

Mgr. Joanna MOSKAŁA

Starszy specjalista inżynieryjno-techniczny w Zakładzie Normalizacji.

Instytut Nafty i Gazu - Państwowy Instytut Badawczy ul. Lubicz 25 A

31-503 Kraków

E-mail: jaonna.moskala@inig.pl 